\title{
Multifunctional elastin-like polypeptide renders $\beta$-glucosidase enzyme phase transition and high stability
}

\author{
Yang Zhou', Xiaofeng Li ${ }^{1}$, Dandan Yan ${ }^{1}$, Frank Addai Peprah ${ }^{1}$, Xingqi Ji', Emmanuella Esi Fletcher ${ }^{1}$,
} Yanwei Wang ${ }^{1}$, Yingying Wang ${ }^{1}$, Jie Gu ${ }^{1}$, Feng Lin ${ }^{2^{*}}$ and Haifeng Shi ${ }^{1^{*}}$

\begin{abstract}
Background: In the enzymatic conversion of biomass, it becomes an important issue to efficiently and cost-effectively degrade cellulose into fermentable glucose. $\beta$-Glucosidase (Bgluc), an essential member of cellulases, plays a critical role in cellulosic biomass degradation. The difficulty in improving the stability of Bgluc has been a bottleneck in the enzyme-dependent cellulose degradation. The traditional method of protein purification, however, leads to higher production cost and a decrease in activity. To simplify and efficiently purify Bgluc with modified special properties, Bgluc-tagged ELP and His with defined phase transitions was designed to facilitate the process.

Results: Here, a novel binary ELP and His tag was fused with Bgluc from termite Coptotermes formosanus to construct a Bgluc-linker-ELP-His recombinant fusion protein (BglucLEH). The recombinant plasmid Bgluc expressing a His tag (BglucH) was also constructed. The BglucLEH and BglucH were expressed in E. coli BL21 and purified using inverse transition cycling (ITC) or Ni-NTA resin. The optimum salt concentration for the ITC purification of BglucLEH was $0.5 \mathrm{M}$ $\left(\mathrm{NH}_{4}\right)_{2} \mathrm{SO}_{4}$ and the specific activity of BglucLEH purified by ITC was $75.5 \mathrm{U} / \mathrm{mg}$ for substrate $p$-NPG, which was slightly higher than that of BglucLEH purified by Ni-NTA $(68.2 \mathrm{U} / \mathrm{mg})$. The recovery rate and purification fold of BglucLEH purified by ITC and Ni-NTA were $77.8 \%, 79.1 \%$ and 12.60, 11.60, respectively. The results indicated that purification with ITC was superior to the traditional Ni-NTA. The $K_{m}$ of BglucLEH and BglucH for $p$-NPG was 5.27 and $5.73 \mathrm{mM}$, respectively. The $K_{\text {ca }} t / K_{m}\left(14.79 \mathrm{~S}^{-1} \mathrm{mM}^{-1}\right)$ of BglucLEH was higher than that of BglucH $\left(12.10 \mathrm{~S}^{-1} \mathrm{mM}^{-1}\right)$. The effects of ELP tag on the enzyme activity, secondary structure and protein stability were also studied. The results showed that ELP tag did not affect the secondary structure or enzyme activity of Bgluc. More importantly, ELP improved the protein stability in harsh conditions such as heating and exposure to denaturant.
\end{abstract}

Conclusion: The Bgluc-linker-ELP-His system shows wide application prospect in maintaining the activity, efficient purification and improving the stability of Bgluc. These properties of BglucLEH make it an interesting tool to reduce cost, to improve the efficiency of biocatalyst and potentially to enhance the degradation of lignocellulosic biomass.

Keywords: Coptotermes formosanus, Termites, $\beta$-Glucosidase, Glycosyl hydrolases, Elastin-like polypeptides, Protein purification, Protein stability, Biofuels

\footnotetext{
*Correspondence: wwlinfeng@163.com; shihf@ujs.edu.cn

${ }^{1}$ Institute of Life Sciences, Jiangsu University, No. 301 Xuefu Road,

Zhenjiang 212013, People's Republic of China

${ }^{2}$ Key Laboratory of Healthy Freshwater Aquaculture, Ministry

of Agriculture, Zhejiang Institute of Freshwater Fisheries, Huzhou 313001,

People's Republic of China
}

(c) The Author(s) 2019. This article is distributed under the terms of the Creative Commons Attribution 4.0 International License (http://creativecommons.org/licenses/by/4.0/), which permits unrestricted use, distribution, and reproduction in any medium, provided you give appropriate credit to the original author(s) and the source, provide a link to the Creative Commons license, and indicate if changes were made. The Creative Commons Public Domain Dedication waiver (http://creativecommons.org/ publicdomain/zero/1.0/) applies to the data made available in this article, unless otherwise stated. 


\section{Background}

Lignocellulose, mainly comprising of cellulose (20-50\%), hemicelluloses (15-35\%) and lignin (18-35\%), is the most abundant biomass on earth and is recognized as a potential sustainable source for biofuels. Cellulose is a polysaccharide composed of long linear chains of D-glucose linked by $\beta-(1,4)$ glycosidic bonds [1]. Enzymatic hydrolysis of cellulose requires the synergistic action of endoglucanases (EG, EC 3.2.1.4), cellobiohydrolases (CBH, EC 3.2.1.91), and $\beta$-glucosidases (Bgluc, EC 3.2.1.21) [2]. The $\mathrm{CBH}$ acts on the ends of the cellulose chain and releases $\beta$-cellobiose as the end product; EG randomly attacks the internal O-glycosidic bonds, resulting in glucan chains of different lengths; and the Bgluc catalyzes the hydrolysis of $\beta$-glycosidic bond in glucosyl derivatives like arylglucosides, cellobiose, or higher cellooligosaccharides to produce glucose. Bgluc themselves are also subject to product inhibition by glucose [3].

These enzymes are members of the glycoside hydrolases family (GHF) with hydrolyze the glycosidic bonds between carbohydrates. Termites have developed cellulose digestion capabilities with endogenous and symbiotic cellulases, with the endogenous cellulolytic enzymes consisting of EG and Bgluc [4]. This dual-cellulose digestion system appears to result in high digestibility of cellulose. The lower termites, Coptotermes formosanus, are often nicknamed the super-termite because of its destructive habits due to the large size of its colonies and its ability to degrade lignocellulosic polysaccharides efficiently at a rapid rate [5]. Based on the amino acid sequences, Bglucs have been classified into GHF 1, 3, 5, 9, 30 and 116 [6]. In termite-derived endogenous cellulases, EGs are affiliated with the GHF9; while all endogenous Bglucs belong to GHF1, except for one putative endogenous GHF3 Bgluc [1].

Bgluc plays a vital role in cellulose hydrolysis by undertaking the rate-limiting final step of hydrolyzing cellobiose, which is an intermediate product of cellulose hydrolysis and also a strong inhibitor of cellulase activities [7]. It is a common practice to supplement Bgluc to increase the efficiency of cellulose saccharification. The insufficiency of Bgluc in this cellulase complex is one of the bottlenecks in efficient cellulose hydrolysis [8]. To efficiently digest the cellulase in biomass, certain issues need to be addressed and resolved. First, much effort needs to be taken to improve the activity of Bgluc, or a wide variety of Bgluc can be acquired at lower cost or at best to utilize effective methods such as recombinant enzyme. Second, the traditional column chromatography purification has some disadvantages, such as been time-consuming, irreversible adsorption and low reproducibility, which calls for the need to develop an inexpensive, productive and simple purification procedure.
Third, to increase the utilization of enzymes, enzyme engineering needs to focus on improving stability and decreasing the loss of activity in harsh conditions such as heating and exposure to denaturant [9]. However, there is a lack of an integrated system for the production, efficient purification, and techniques for improving Bgluc stability for its large-scale application as a biocatalyst for biomass conversion into bioethanol.

Elastin-like polypeptides (ELPs) are repetitive artificial polypeptides derived from recurring amino acid sequences found in the hydrophobic domain of tropoelastin [10]. The most commonly used ELP has the pentapeptide sequence (VPGXG) ${ }_{n}$, where the guest residue $\mathrm{X}$ can be occupied by any amino acid except proline (because proline destroys the inverse phase transition property of the ELP), and " $n$ " represents the number of pentapeptide repeats in the ELP [11]. ELPs exhibit a quick and thermodynamic reversible phase transition behavior at a specific temperature referred to as the inverse transition temperature $\left(T_{\mathrm{t}}\right)[12,13]$. ELPs are structurally disordered and soluble in aqueous solution below their $T_{\mathrm{t}}$; whereas, intramolecular contacts between the nonpolar regions result in aggregation, and hence precipitation above the $\mathrm{T}_{t}[14]$. This transition of ELP is a reversible process, so the ELP can be fully resolubilized when the solution temperature is below the $T_{\mathrm{t}}$. The transition of ELPs and their fusion proteins can also be isothermally triggered by reducing the $T_{\mathrm{t}}$ below solution temperature by the addition of salts from the Hofmeister [15].

The inverse transition cycling (ITC) provides a new and efficient strategy for protein purification. This technique can be used to achieve a rapid, high protein purity using the thermally triggered phase-separation behavior of ELP to enable a simple separation and purification of their fusion proteins $[11,16]$. In this study, a gene from $C$. formosanus encoding Bgluc tagged with the novel multifunctional binary protein, ELP\&His (Bgluc-Linker-ELP-6xHis, BglucLEH) was synthesized. Furthermore, the recombinant plasmid expressing the fusion protein Bgluc with a His tagged (BglucH) was also constructed. To achieve biological activity, a short peptide linker ((GGGGS) $)_{3}$ ) was inserted between the Bgluc and the ELP. The recombinant BglucLEH and BglucH were cloned into pET-28a(+), and expressed in the E. coli BL21. BglucLEH was purified with ITC and $\mathrm{Ni}-\mathrm{NTA}$ resin separately, whereas BglucH was purified with only Ni-NTA resin. We evaluated the purification efficiency by comparing BglucLEH purified by ITC with BglucLEH and BglucH purified by Ni-NTA resin. Finally, ELP labeling effects on the kinetic parameters, enzyme activity and stability were also studied. 


\section{Results}

The design of fusion protein (BglucLEH and BglucH) and the construction of recombinant expressional plasmid Bgluc from the termite $C$. formosanus, a 479-amino acid enzyme, was encoded in a 1437-bp DNA fragment. The length of the DNA fragments encoding linker, ELP and His was 45, 750 and $18 \mathrm{bp}$, respectively, as shown in Fig. 1. The length of the DNA fragments of BglucLEH was 2268 bp. Furthermore, the recombinant plasmid pET28a(+)-Bgluc (BglucH) containing His-tagged Bglu was previously constructed [5]. The recombinant plasmids were verified by DNA sequencing.

\section{Production of BglucH and BglucLEH}

The molecular weights of BglucH and BglucLEH are around 56 and $82 \mathrm{kDa}$, respectively. SDS-PAGE analysis of the soluble and insoluble fractions following expression in E. coli revealed that BglucH and BglucLEH accumulated primarily in an insoluble fraction at $37{ }^{\circ} \mathrm{C}$. The induction of protein expression at lower temperatures increases the yield of soluble recombinant proteins in $E$. coli $[17,18]$. To obtain active soluble proteins, we induced the expression of BglucH and BglucLEH at $25{ }^{\circ} \mathrm{C}$ with $1 \mathrm{mM}$ isopropyl-beta-D-thiogalactopyranoside (IPTG) (Additional file 1: Figure. S1a), and the result showed that BglucH and BglucLEH were produced in soluble form (Additional file 1: Figure. S1b).

\section{Purification of BglucH and BglucLEH}

The effect of Hofmeister series ions on the $T_{\mathrm{t}}$ is given as: $\mathrm{NH}_{4}{ }^{+}>\mathrm{K}^{+}>\mathrm{Na}^{+}>\mathrm{Mg}^{2+}>\mathrm{Ca}^{2+}>\mathrm{Mn}^{2+}>\mathrm{Cu}^{2+} ; \quad \mathrm{SO}_{4}{ }^{2-}>$ $\mathrm{HPO}_{4}{ }^{2-}>\mathrm{CH}_{3} \mathrm{COO}^{-}>\mathrm{Cl}^{-}>\mathrm{Br}^{-}>\mathrm{NO}_{3}{ }^{-}>\mathrm{SCN}^{-}$. According to the series, $1 \mathrm{M} \mathrm{NaH}_{2} \mathrm{PO}_{4}, 1 \mathrm{M}\left(\mathrm{NH}_{4}\right)_{2} \mathrm{SO}_{4}$,
$1 \mathrm{M} \mathrm{Na}_{2} \mathrm{SO}_{4}, 2.5 \mathrm{M} \mathrm{NaCl}$ were selected to purify the BglucLEH. The expression levels and purity of collected fractions were determined by SDS-PAGE (Fig. 2, Lane 11-14). According to the above result (Fig. 2), $\left(\mathrm{NH}_{4}\right)_{2} \mathrm{SO}_{4}$ was selected as precipitant and the effect of the various concentrations of $\left(\mathrm{NH}_{4}\right)_{2} \mathrm{SO}_{4}(0.1,0.3,0.5,0.7,1.0 \mathrm{M})$ on the purification efficiency was investigated. A clear band at size around $82 \mathrm{kDa}$ appeared obviously indicating that 0.3-0.7 M $\left(\mathrm{NH}_{4}\right)_{2} \mathrm{SO}_{4}$ could be used to purify BglucLEH by ITC (Fig. 3a, lane 4, 5, 6). Meanwhile, it can be seen from Fig. $3 \mathrm{~b}$ that the purification fold reached a maximum value of 13.3 at $0.5 \mathrm{M}\left(\mathrm{NH}_{4}\right)_{2} \mathrm{SO}_{4}$. With the increase of $\left(\mathrm{NH}_{4}\right)_{2} \mathrm{SO}_{4}$ concentration from $0.7 \mathrm{M}$ to $1.0 \mathrm{M}$, the purification fold decreased gradually. The recovery rate of the BglucLEH reached the maximum value $(80 \%)$ at $0.5 \mathrm{M}\left(\mathrm{NH}_{4}\right)_{2} \mathrm{SO}_{4}$. Thus, $0.5 \mathrm{M}\left(\mathrm{NH}_{4}\right)_{2} \mathrm{SO}_{4}$ was identified as the optimum precipitant for the purification of BglucLEH.

The purification of BglucLEH was conducted utilizing two techniques, which are Ni-NTA resin and ITC method because BglucLEH contains His and ELP tags (Fig. 2), and the two methods are independent of each other. BglucH, however. was purified using only Ni-NTA resin because it contains only a His tag (Additional file 1: Figure S2). To compare the ITC with Ni-NTA resin, the purification efficiency of BglucLEH either by ITC or NiNTA resin, and that of BglucH by Ni-NTA resin are summarized in Table 1 . The specific activity of BglucLEH by ITC was $75.50 \mathrm{U} / \mathrm{mg}$, which was slightly higher than that of BglucLEH by Ni-NTA resin $(68.22 \mathrm{U} / \mathrm{mg})(p<0.01)$ and BglucH by Ni-NTA resin $(68.85 \mathrm{U} / \mathrm{mg})(p<0.01)$. The recovery rate and purification fold of the BglucLEH by either ITC or Ni-NTA resin were $77.78 \%, 79.07 \%$ and

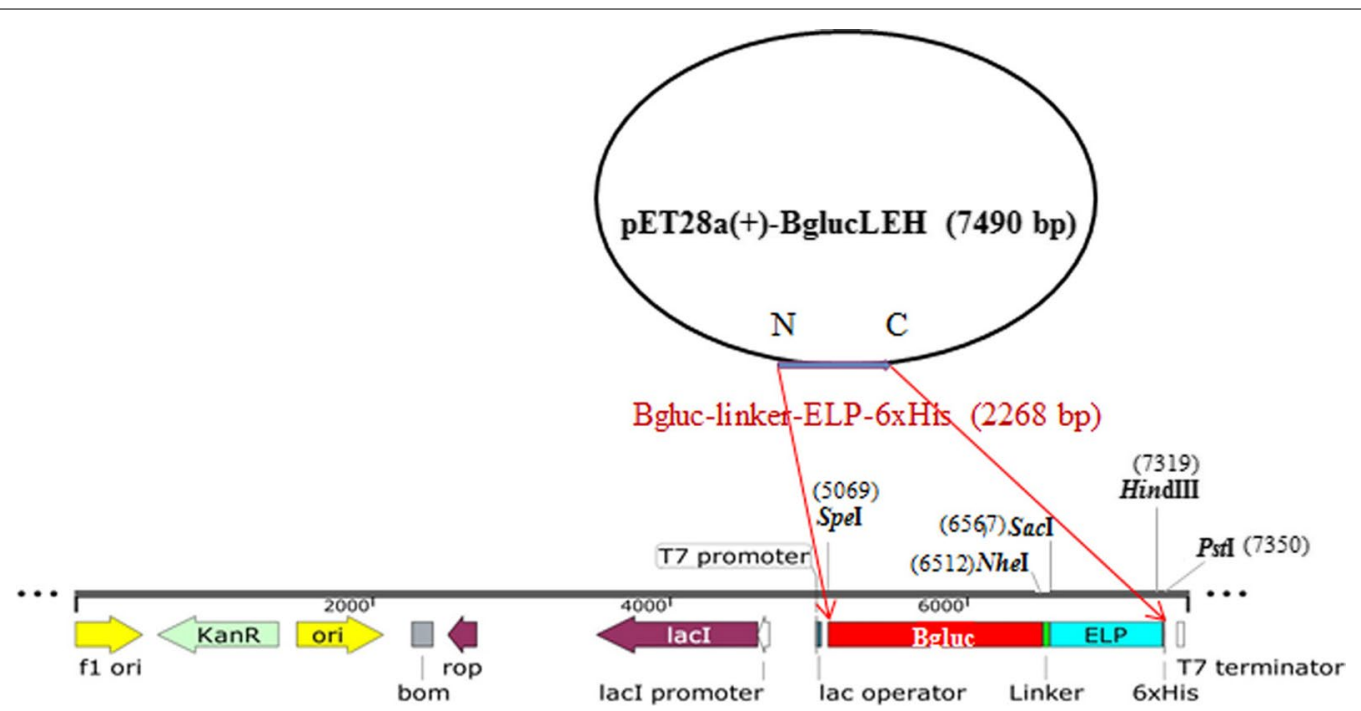

Fig. 1 Schematic diagram of recombinant plasmid pET28a(+)-BglucLEH 


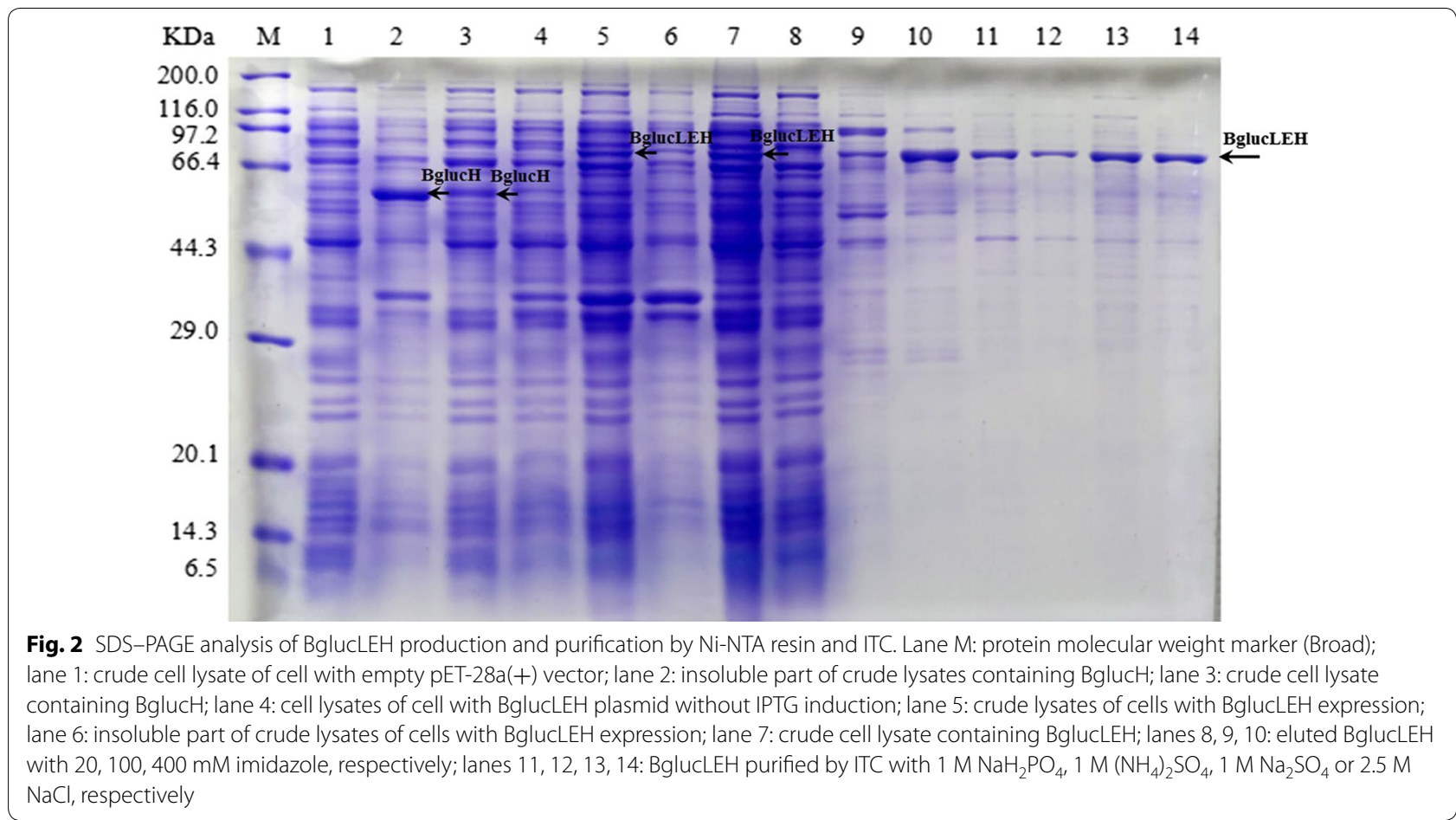

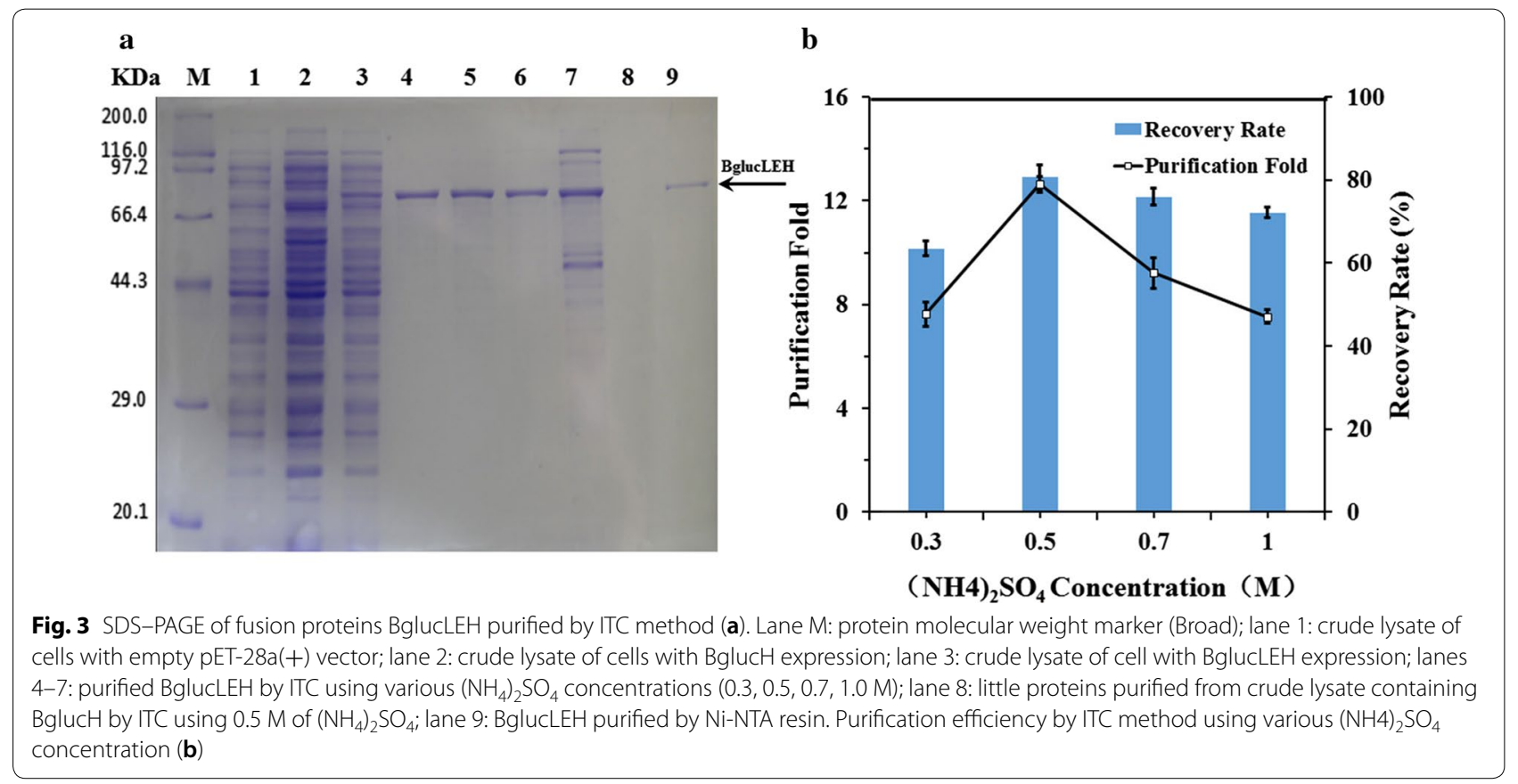

$12.60,11.39$, respectively, and the recovery rate and purification fold of the BglucH by Ni-NTA resin were $75.62 \%$ and 12.14, respectively. Furthermore, the densitometric analysis of SDS-PAGE indicated that the purity of BglucLEH by one-round ITC reached $90 \%$, which showed an excellent performance in the purification process (Fig. 3a, lane 5).

Furthermore, the effect of the number of ITC on the purification was also investigated. The specific activity of BglucLEH by one- and two-round ITC was $75.50 \mathrm{U} / \mathrm{mg}$ 
Table 1 A comparison of purification efficiency between Ni-NTA resin and ITC

\begin{tabular}{|c|c|c|c|c|c|}
\hline Proteins & Total protein (mg) & $\begin{array}{l}\text { Specific activity } \\
\text { (unit/mg) }\end{array}$ & Total activity (unit) & Yield (\%) & $\begin{array}{l}\text { Purification } \\
\text { (fold) }\end{array}$ \\
\hline Cell lysate (all proteins of E. coli contained EP) & $3.25 \pm 0.39$ & $0.08 \pm 0.004$ & $0.263 \pm 0.06$ & & \\
\hline $\begin{array}{l}\text { Cell lysate with expression of } \mathrm{BglucH}^{\mathrm{b}} \text { (all proteins } \\
\text { of E. coli contained BglucH) }\end{array}$ & $6.63 \pm 0.53$ & $5.75 \pm 0.042$ & $37.59 \pm 0.89$ & & \\
\hline Bgluc $\mathrm{H}^{\mathrm{b}}$ in cell lysate & $6.63 \pm 0.53$ & $5.67 \pm 0.35^{*}$ & $37.33 \pm 0.78$ & 100.0 & 1.0 \\
\hline $\begin{array}{l}\text { BglucLEH in cell lysate (all proteins of E. coli } \\
\text { contained BglucLEH) }\end{array}$ & $5.23 \pm 0.34$ & $6.07 \pm 0.46$ & $31.32 \pm 0.65$ & & \\
\hline BglucLEHC in cell lysate & $5.23 \pm 0.34$ & $5.99 \pm 0.54^{*}$ & $31.06 \pm 0.63$ & 100.0 & 1.0 \\
\hline Purified BglucH by Ni-NTA resin & $0.41 \pm 0.09$ & $68.85 \pm 1.19$ & $28.23 \pm 0.51$ & 75.62 & 12.14 \\
\hline Purified BglucLEH by Ni-NTA resin & $0.36 \pm 0.04$ & $68.22 \pm 1.27$ & $24.56 \pm 0.59$ & 79.07 & 11.39 \\
\hline Purified BglucLEH by one round of ITC & $0.32 \pm 0.05$ & $75.50 \pm 1.54$ & $24.16 \pm 0.68$ & 77.78 & 12.60 \\
\hline Purified BglucLEH by two rounds of ITC & $0.27 \pm 0.03$ & $76.22 \pm 1.43$ & $20.58 \pm 0.47$ & 66.26 & 12.72 \\
\hline
\end{tabular}

EP empty plasmid $\mathrm{pET}-28 \mathrm{a}(+)$

a,b,c $2.5 \mathrm{~mL}$ cell extracts was obtained through ultrasonication treatment of $E$. coli collected from $75 \mathrm{~mL}$ LB culture

* Indicates that the specific activity of the empty carrier has been removed

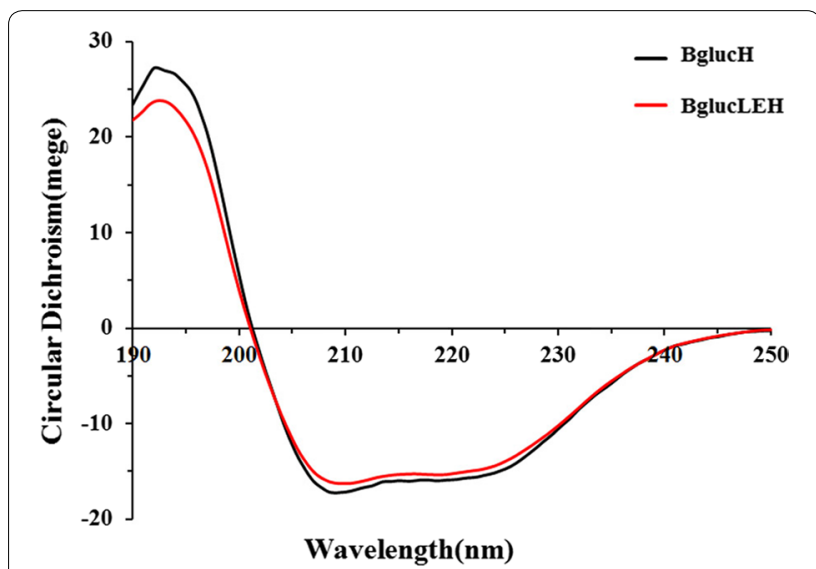

Fig. 4 The circular dichroism spectrum of BglucH and BglucLEH

and $76.22 \mathrm{U} / \mathrm{mg}$, respectively (Table 1 ). The recovery rate and purification fold of the BglucLEH by one- and tworound ITC were $77.8 \%, 66.26 \%$ and $12.60,12.72$, respectively (Table 1). The densitometric analysis of SDS-PAGE showed that the purity of BglucLEH by two rounds of ITC did not significantly increase compared with a single round of ITC (Additional file 1: Figure S3), but decreased the recovery rate (Table 1 ).

\section{ELP tag did not change the secondary structure of Bgluc}

To explore the secondary structure of Bgluc in the presence of ELP, circular dichroism (CD) analysis for BglucH and BglucLEH was performed from 190 to $250 \mathrm{~nm}$. The result showed one positive peak around $196 \mathrm{~nm}$ and two negative peaks trough around $208 \mathrm{~nm}$ and $222 \mathrm{~nm}$, indicating the typical signature for $\beta$-sheet and $\alpha$-helix structure (Fig. 4), respectively. Analysis of the secondary structure propensities for BglucH and BglucLEH from the results showed no significant structure difference (Fig. 4). This indicated that the ELP tag appears to have little effect on the secondary structure of Bgluc.

Optimum pH and temperatures of BglucH and BglucLEH

The influence of temperature and $\mathrm{pH}$ on the activities of BglucLEH was studied compared with BglucH. It was observed that both BglucH and BglucLEH had their highest activities at optimum pH of 5.5 (Fig. 5a), which indicates that ELP tag did not change the optimum $\mathrm{pH}$ of the reaction.

The temperature-dependent activities of BglucH and BglucLEH were studied over the temperature range of $20-80{ }^{\circ} \mathrm{C}$. As shown in Fig. $5 \mathrm{~b}$, the optimum temperature for BglucH and BglucLEH was around at $40{ }^{\circ} \mathrm{C}$. The enzyme activities of both BglucH and BglucLEH gradually decreased when the temperature was elevated above $40{ }^{\circ} \mathrm{C}$. The BglucLEH was, however, found to retain more than $40 \%$ of its activity at $60{ }^{\circ} \mathrm{C}$, while BglucH retained only $3 \%$, suggesting that ELP tag may increase the thermal stability of BglucH.

\section{Kinetic parameters of BglucH and BglucLEH}

The kinetic parameters of BglucH and BglucLEH were conducted using $p$-nitrophenyl- $\beta$-D-glucopyranoside ( $p$ NPG) as substrate under optimal conditions (Table 2). A Lineweaver-Burk plot was used to calculate the $K_{\mathrm{m}}$ and $V_{\max }$ values (Additional file 1: Figure $\mathrm{S} 4$ ). The affinity $\left(K_{\mathrm{m}}\right)$ of BglucLEH for $p$-NPG was $5.27 \mathrm{mM}$, which was slightly lower than that of BglucH $(5.73 \pm 0.4 \mathrm{mM})$. The catalytic efficiency $\left(K_{\text {cat }} / K_{\mathrm{m}}\right)$ of BglucLEH $\left(14.79 \pm 0.5 \mathrm{~S}^{-1} \mathrm{mM}^{-1}\right)$ for $p$-NPG was higher than that of BglucH (12.10 \pm 0.7 $\mathrm{S}^{-1} \mathrm{mM}^{-1}$ ). The $V_{\mathrm{m}}$ of the BglucH and BglucLEH for $p$ NPG were 0.037 and $0.098 \mathrm{mM} \mathrm{min}^{-1}$, respectively. 

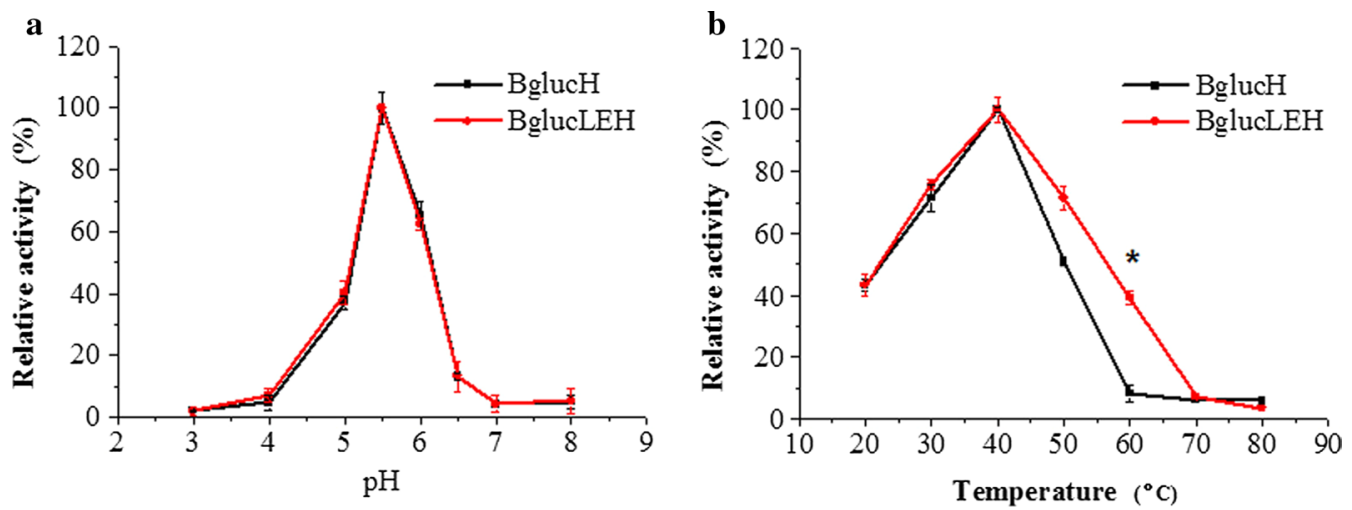

Fig. 5 Effects of $\mathrm{pH}(\mathbf{a})$ and temperature (b) on the enzyme activity. Each value in the panel represents the mean $\pm \mathrm{SD}(n=3)$. Asterisks denote statistical significance. ${ }^{*} p<0.05,{ }^{* *} p<0.01$

Table 2 Kinetic parameters of BglucH and BglucLEH in hydrolysis of $p$-NPG

\begin{tabular}{lcccc}
\hline Enzyme & $\boldsymbol{K}_{\mathbf{m}}(\mathbf{m M})$ & $\boldsymbol{K}_{\text {cat }}\left(\mathbf{S}^{-\mathbf{1}}\right)$ & $\boldsymbol{V}_{\mathbf{m}}\left(\mathbf{m M ~ m i n}^{-\mathbf{1}}\right)$ & $\begin{array}{l}\boldsymbol{K}_{\text {cat }} / \boldsymbol{K}_{\mathbf{m}} \\
\left(\mathbf{S}^{\mathbf{1}} \mathbf{m} \mathbf{M}^{-\mathbf{1}}\right)\end{array}$ \\
\hline BglucH & $5.73 \pm 0.4$ & $69.36 \pm 1.1$ & $0.037 \pm 0.006$ & $12.10 \pm 0.7$ \\
BglucLEH & $5.27 \pm 0.5$ & $77.94 \pm 0.9$ & $0.098 \pm 0.003$ & $14.79 \pm 0.5$ \\
\hline
\end{tabular}

\section{ELP tag increased protein stability}

The purified BglucH and BglucH EH were stored at $4{ }^{\circ} \mathrm{C}$ and $25^{\circ} \mathrm{C}$ for 28 days. The relative enzyme activities were evaluated every 4 days as shown in Fig. 6a. The purified BglucLEH and BglucH retained $90 \%$ and $75 \%$ of its original activity when stored at $4{ }^{\circ} \mathrm{C}$ for 28 days, respectively. BglucH lost $70 \%$ of its enzyme activity at $25^{\circ} \mathrm{C}$ at the 28 th day, while BglucLEH lost only about $30 \%$ of its activity.

To study the thermal stability, the BglucH and BglucLEH were incubated at various temperatures for $30 \mathrm{~min}$. As shown in Fig. 6b, BglucH and BglucLEH lost 90\% and
$20 \%$ of its initial activity when the temperature reached $60{ }^{\circ} \mathrm{C}$, respectively. When the temperature reached $70{ }^{\circ} \mathrm{C}$, BglucH lost almost all activity, while BglucLEH retained $55 \%$ of its initial activity. The results indicated that the thermal stability and storage stability of BglucLEH were higher than that of BglucH. Moreover, the effect of $\mathrm{pH}$ on the stability of BglucH and BglucLEH was measured on enzymes after incubation in buffer of different $\mathrm{pH}$ at $40{ }^{\circ} \mathrm{C}$ for $30 \mathrm{~min}$. It was, however, observed that the $\mathrm{pH}$ stability of BglucLEH was not different from that of BglucH (data not shown), which indicated that ELP did not improve the enzyme's $\mathrm{pH}$ tolerance.

Guanidine hydrochloride is a common protein denaturant. In this study, BglucH and BglucLEH were incubated with various concentrations of guanidine hydrochloride, and then the changes in secondary structure were monitored. The Fig. 7a, b shows the CD spectra of BglucH and BglucLEH treated with various concentrations of guanidine hydrochloride. The denaturation curve (Fig. 7c) indicates that BglucH lost 15.7\%, 26.1\%, 43.4\% of
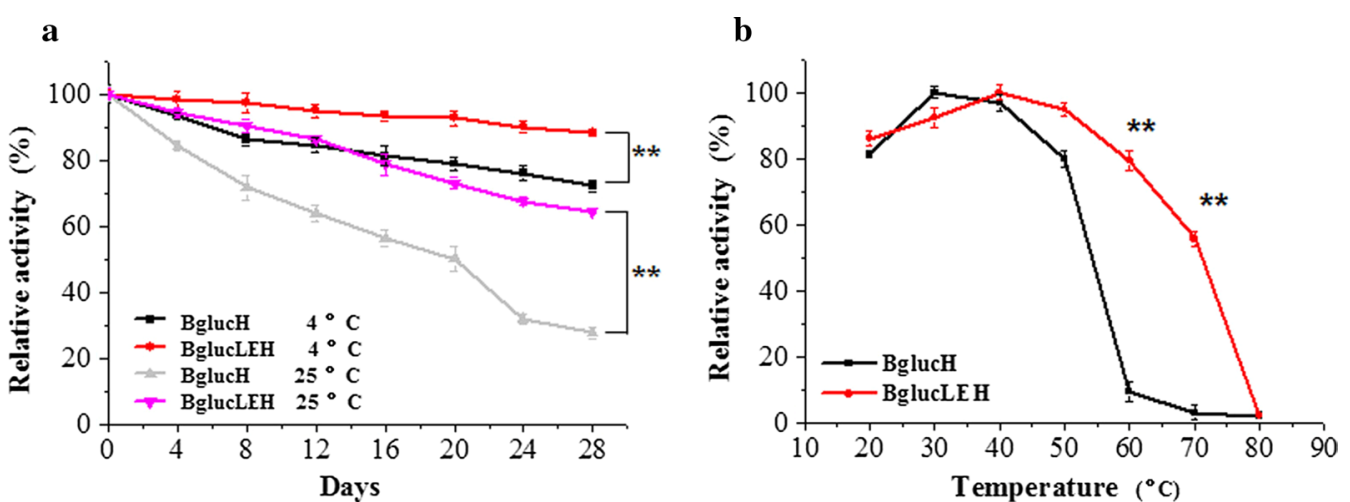

Fig. 6 The experiment of stability. Storage stability dependent on time and temperature (a). Thermal stability (b). Each value in the panel represents the mean $\pm \mathrm{SD}(n=3)$. Asterisks denote statistical significance. ${ }^{*} p<0.05,{ }^{* *} p<0.01$ 

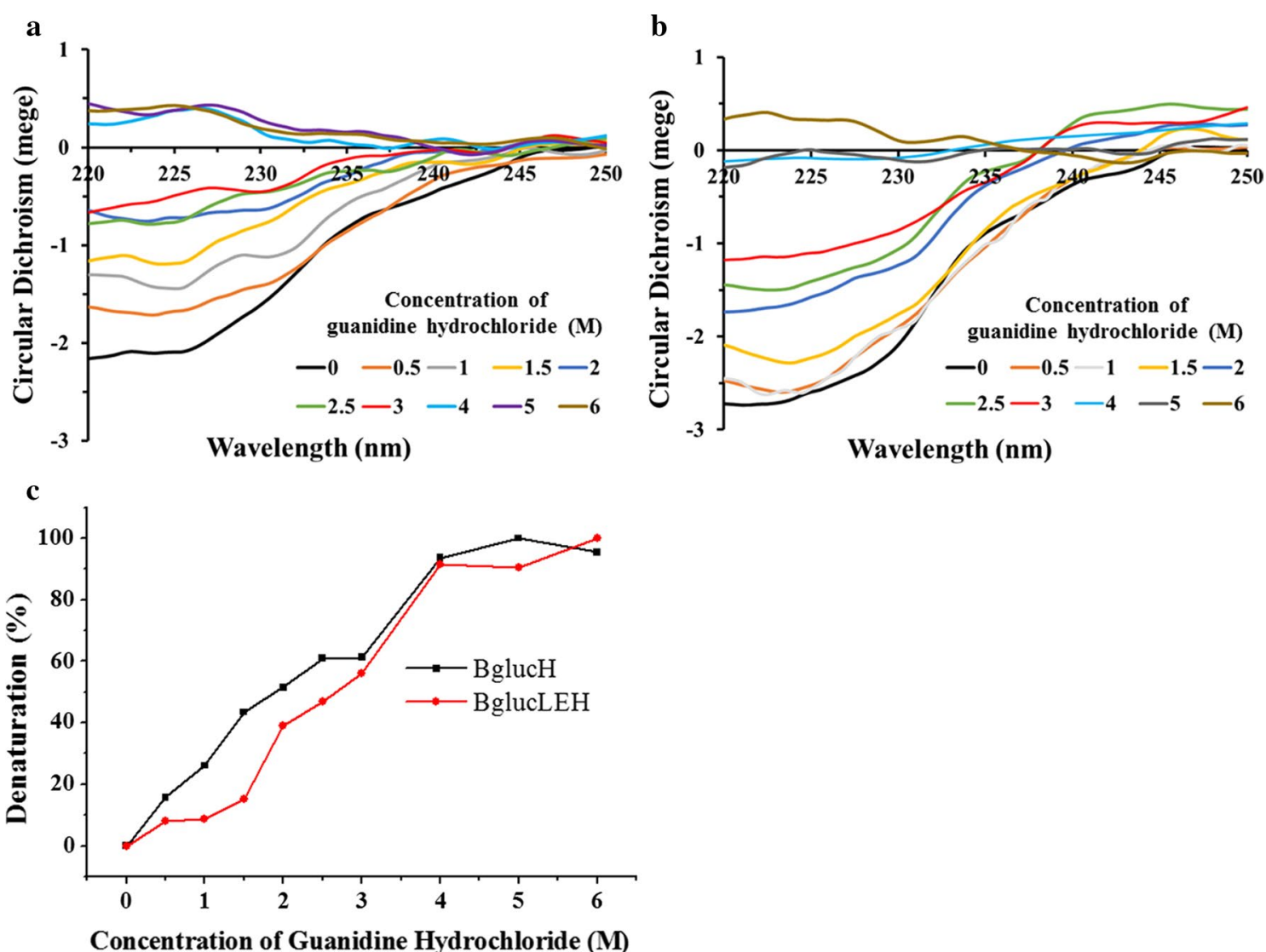

Fig. 7 The circular dichroism spectra of BglucH (a) and BglucLEH (b) treated with various concentration of guanidine hydrochloride. The denaturation curve of BglucH and BglucLEH at $230 \mathrm{~nm}$ treated with various concentration of guanidine hydrochloride (c)

its secondary structure at $0.5,1,1.5 \mathrm{M}$ guanidine hydrochloride, while the secondary structure of BglucLEH lost only $7.9 \%, 8.5 \%, 15.0 \%$ at $0.5,1,1.5 \mathrm{M}$ guanidine hydrochloride, respectively. Taken together, ELP tag increased the protein stability against both heat and chaotropic denaturant.

\section{Discussion}

Wood-feeding termites are well known as efficient cellulose decomposers that have the ability to degrade lignocelluloses with their unique enzyme complexes. Bgluc is known as a multifunctional enzyme for social maintenance in terms of both cellulose digestion and social communication in termites [19]. Bgluc from termites, such as C. formosanus [20, 21], C. gestroi [22, 23], C. secundus [24], R. flavipes [25], M. barneyi [26], N. koshunensis [27], N. takasagoensis [28, 29] have been identified. All of the reported Bglucs from termites were identified as GH1 [30]. In our previous study, three types of Bgluc homologs (CfGlu1C, CfGlu1B, CfGlu1D) from the termite C. formosanus were identified, and CfGlu1B has a high degree of amino acid similarity with the Bgluc from O. formosanus, $N$. koshunensis, C. gestroi, and $T$. reesei [5]. Moreover, Bgluc form R. speratus (RsBGI) has also been identified to be $86 \%$ identical to Bgluc from $C$. formosanus CfGlu1B [19].

Bgluc from some other organisms has been heterologously expressed and purified. The purity of Bgluc from N. takasagoensis (G1mgNtBG1) using Ni-NTA resin increased by 6.7 -fold with a recovery rate of $83 \%$, and a specific activity of $5.83 \mathrm{U} / \mathrm{mg}$ [29]. The yield and purification fold of Bgluc from $M$. annandalei using Ni-NTA resin were found to be $7.5 \%$ and 19.1 -fold, respectively [30]. The yield and purification fold of Bgluc from Chinese snail using Ni-NTA resin were $21.0 \%$ and 9.0 -fold, respectively [31]. The specific activity and yield of Bgluc from T. amestolkiae using HiTrap Capto Adhere, Mono Q 5/50 and Superdex 75 HR 10/30 were 50.4 U/mg, $78.5 \mathrm{U} /$ $\mathrm{mg}, 82.6 \mathrm{U} / \mathrm{mg}$, and $76.5 \%, 57.3 \%, 6.3 \%$, respectively [32]. The purification fold and yield of the Bgluc from $M$. thermophila using gel filtration on Sephacryl S-100 were 11.2-fold and $25.5 \%$, respectively [33]. The Bgluc from $P$. piceum was $8.7-$ fold with a specific activity of $80 \mathrm{U} / \mathrm{mg}$ against $p$-NPG using gel filtration chromatography [34]. 
In this study, our data showed that the specific activity, yield and purification fold of purified BglucLEH by ITC and Ni-NTA resin were $75.50 \mathrm{U} / \mathrm{mg}, 77.78 \%, 12.60$-fold; and $68.22 \mathrm{U} / \mathrm{mg}, 79.07 \%, 11.39$-fold, respectively. The results indicate that the purification performance of ITC was equivalent to or better than that of Ni-NTA resin. Performance of several rounds of ITC indicated that a heterogeneous solution of proteins gradually become more homogeneous, eventually resulting in substantially higher purity of recombinant ELP fusion protein [35]. However, our data showed that the purity of BglucLEH by two rounds of ITC did not significantly increase compared with a single round of ITC. It, however, reduced the yield of ELP fusion protein. One round of ITC was sufficient for BglucLEH purification. In summary, the purification performance of ITC had a comparative advantage, that is, been simple, time efficient, inexpensive and highly efficient, compared with conventional column chromatography. A comparison of the biochemical properties and kinetic performance of Bgluc from different species to $p$-NPG is shown in Table 3. Bgluc from fungi tends to have high catalytic performance compared to that of other species. Commercial cellulases are mainly from fungi, especially $T$. reesei. Bgluc produced by other species must be added to a $T$. reesei enzyme mixture to increase the efficiency of the hydrolysis of cellulosic substrates [36]. The catalytic efficiency of Bgluc from termites (such as $R$. flavipes [25], C. gestroi [22], $M$. annandalei [30] and C. formosanus [5]) tends to be lower compared to Bgluc from fungi [32, 37-43]. In termites, it was reported that the optimum $\mathrm{pH}$ and temperature of Bgluc were within $\mathrm{pH} 5.0-6.5$ and $40-60{ }^{\circ} \mathrm{C}$, respectively $[5,22,25-27,30]$. Here, the optimum $\mathrm{pH}$ and temperature of BglucH and BglucLEH were identified as 5.5 and $40{ }^{\circ} \mathrm{C}$.

$\mathrm{CD}$ analysis of Bgluc from C. gestroi (CgBG1) showed a negative peak ( $\alpha$-helical) at $222 \mathrm{~nm}$ and a positive peak ( $\beta$-sheets) at $192 \mathrm{~nm}$. Based on the CgEG1 model, the secondary structure of Bgluc was primarily $\alpha$-helical (43.6\%) followed by $\beta$-sheets (13.6\%) and unstructured loops $(42.8 \%)$ [22]. Our results showed one positive peak at $196 \mathrm{~nm}$ ( $\beta$-sheets) and two negative peaks ( $\alpha$-helical) at $208 \mathrm{~nm}$ and $222 \mathrm{~nm}$. The CD analysis of BGL-2 (Bgluc from T. amestolkiae) revealed that all BGL-2 forms have a typical spectrum of $\alpha+\beta$ folded structures, and the spectrum of BGL-2T* (a mutation of BGL-2) lacked the minimum at $208 \mathrm{~nm}$, a typical signature of proteins with cellulose binding domain, which may be one of the reasons for its increased stability to temperature and $\mathrm{pH}$ [32].

ELP fusion proteins can increase proteins' solubility and maintain its biological activity as well as its physical properties [45-48]. Floss et al. [49] reported that scFv ELP fusions can accumulate to very high levels, but the ELP does not affect the protein assembly, folding or the antigen-binding properties of antibodies. The

Table 3 Enzymatic properties of Bgluc from termites and other species to $p$-NPG

\begin{tabular}{|c|c|c|c|c|c|c|}
\hline Source organism & $\begin{array}{l}\text { Optimum } \\
\text { temperature }\left({ }^{\circ} \mathrm{C}\right)\end{array}$ & Optimum pH & $K_{\mathrm{m}}(\mathrm{mM})$ & $K_{\text {cat }}\left(\mathrm{s}^{-1}\right)$ & $\begin{array}{l}K_{\text {cat }} / K_{\mathrm{m}} \\
\left(\mathrm{s}^{-1} \mathrm{mM}^{-1}\right)\end{array}$ & References \\
\hline Talaromyces leycettanus & 75 & 4.5 & 0.18 & 1664 & 9096 & {$[37]$} \\
\hline Trichoderma reesei & 40 & 5 & 0.09 & 118 & 1311 & [38] \\
\hline Talaromyces amestolkiae & 40 & 5 & 0.41 & 485 & 1167 & {$[32]$} \\
\hline Aspergillus japonicus & 40 & 5 & 0.6 & 259 & 431.7 & {$[38]$} \\
\hline Aspergillus niger & 40 & 4 & 2.2 & 917 & 416.8 & {$[39]$} \\
\hline Myceliophthora thermophila & 40 & 5 & 0.39 & 147 & 377 & {$[40]$} \\
\hline Thermoascus aurantiacus & 60 & 4.5 & 0.11 & 242 & 2200 & {$[41]$} \\
\hline Penicillium verruculosum & 40 & 5 & 0.44 & 160 & 363.6 & {$[42]$} \\
\hline Fomitopsis palustris & 50 & 5 & 0.12 & 721 & 6008 & {$[43]$} \\
\hline Nasutitermes takasagoensis & 65 & 5.5 & 0.67 & ND & ND & {$[29]$} \\
\hline Reticulitermes flavipes & 40 & 7 & 1.66 & 22.92 & 13.80 & {$[25]$} \\
\hline Neotermes koshunensis & 40 & 5 & 0.77 & ND & ND & {$[27]$} \\
\hline Coptotermes gestroi & 55 & 5 & 1.59 & 57.19 & 35.99 & {$[22]$} \\
\hline Macrotermes barneyi & 45 & 5 & ND & ND & ND & {$[26]$} \\
\hline Microcerotermes annandalei & $50-55$ & $5-6$ & 1.47 & 8.98 & 6.12 & {$[30]$} \\
\hline Globitermes sulphureus & 90 & 6 & 0.18 & ND & ND & {$[44]$} \\
\hline Coptotermes formosanus & 40 & 5 & 2.20 & 60.7 & 27.0 & {$[5]$} \\
\hline Coptotermes formosanus & 40 & 5.5 & 5.73 & 69.36 & 12.10 & This work \\
\hline
\end{tabular}

ND not determined 
antibody-ELP fusion proteins have been reported to retain the parent antibody's ability to bind antigen, albeit with slightly reduced potency [45]. A levansucraseELP fusion protein was expressed in E. coli, and levansucrase activity was not interfered by the ELPs tag [47]. The fusion protein comprising of ELP and KGF retained the functional characteristics of KGF and elastin as evidenced by its enhancement of keratinocyte and fibroblast proliferation [50]. Here, our data showed that ELP did not affect the protein production, enzyme activity or the kinetic parameters of BglucH.

The guest residue composition and chain length of ELP are two parameters that affect the $\mathrm{T}_{t}$. The hydrophobic guest residues and more chain lengths is associated with lower $T_{\mathrm{t}}$, while the hydrophilic guest residues and less chain lengths produce higher $T_{\mathrm{t}}$. Furthermore, placing the ELP at the C-terminus (protein-ELP) or $\mathrm{N}$-terminus (ELP-Protein) of the target protein controls expression level and activity of elastin-like polypeptide fusion proteins [51]. Protein-ELP fusions have a greater level of expression and specific activity levels than ELP-protein fusions [51, 52]. One explanation is that ELP-protein increases the fraction of misfolded, and less active conformers, which are also preferentially degraded compared to C-terminus ELP fusion (protein-ELP) [51]. Here, we designed a 50 repeating pentapeptide sequence, Val-Pro-Gly-Val-Gly (VPGVG) ${ }_{50}$, and placed the ELP at the $\mathrm{C}$-terminus of Bgluc.

Bgluc has attracted the attention of researchers to improve the enzyme's activity and thermostability through bioengineering technology due to its multifunctional role and industrial usefulness. For example, Xia et al. [37] identified and overexpressed a novel Bgluc with high specific activity and high catalytic efficiency in $P$. pastoris, and enhanced the $\mathrm{pH}$ stability by reducing the $O$-glycosylation. Liu et al. [53] demonstrated a combinatorial selection/screening strategy for finding thermostable Bgluc mutants. The Bgluc mutations from T. reesei resulted in shift of optimal temperature to $50^{\circ} \mathrm{C}$, at which the wild type was almost inactive [54]. Moreover, the Bgluc mutant VM2 from T. fusca with three amino acid changes has been reported to be more thermostable [55].

ELP fusion proteins have enhanced thermal stability and improved the circulating half-life and long-term efficacy of therapeutic ELP fusion proteins [56]. To improve the stability of engineered biopolymers against denaturing agents and oxidants, the biopolymers can be fused to enzymes to protect them from decomposition, while maintaining their molecular integrity over an extended period of time. A study by Liu et al. [57] fused collagenlike polypeptide (CLP) to an ELP, and separately fused them to the enzymes SOD and DAAO. The result showed that SOD-CLP-ELP and DAAO-CLP-ELP were more resistant to urea denaturation than SOD and DAAO alone. Udo et al.s team showed that therapeutic proteins fused with ELP possessed a substantially longer serum half-life compared to the non-ELP fusion proteins [58]. ELP forms hydrogen bonds not only with water molecules, but also with other ELP molecules [59]. The longer the ELP sequence repeats, the more hydrogen bonds it contains which provide the most general explanation for the thermal stability in proteins [60]. Cho et al's team also speculated from their data that hydrogen bonding related to structure formation rather than hydrophobicity and was the key factor in the stabilization of collapsed state of ELPs [59]. Furthermore, the organized reversible particles formed by ELP at high temperature will restrict the movement of the enzyme covalently linked, to prevent the enzyme form irreversible aggregation at high temperature. We also demonstrated that the ELP fusion enzyme has higher stability to denaturants compared to the enzyme without ELP. The denaturant competes to form hydrogen bond with amino acids in protein instead of the protein internal hydrogen bonds which stabilizes protein.

ELP-mediated purification may prove as an inexpensive and highly efficient form of purification, but further removal of ELP tags remains a challenge. To solve this problem, the Chilkoti lab [61], Wood lab [62, 63] and Chen lab [64] combined ELP proteins with self-cleaving inteins, which significantly simplified the process. From this study, however, we found that ELP tag neither affected the biological activity of the enzyme nor its structural integrity but rather improved its stability, and as a result removal of the ELP tag from the purified enzyme was not of prime importance for this protein.

We also examined the reusability of the BglucLEH, and the result showed that the purification capacity of the BglucLEH was below 20\% in second purification cycles compared with first purification cycles (data not shown), which indicated that ELP did not increase the enzyme's reusability. Immobilization of enzyme is an applied technique that improves the stability and reusability of an enzyme, making it an economically feasible process $[65$, 66]. Immobilization using a covalent coupling is found to be better than a physical adsorption in binding strength. In our previous study, a novel $\mathrm{Fe}_{3} \mathrm{O}_{4} / \mathrm{PMG} / \mathrm{IDA}-\mathrm{Ni}^{2+}$ nanoparticles were synthesized, and protein with His tag was immobilized onto their surface through combination with the imidazole group and $\mathrm{Ni}^{2+}$ [65]. The binary ELP\&His tag could also be used to immobilize BglucLEH onto $\mathrm{Fe}_{3} \mathrm{O}_{4} /$ PMG/IDA-Ni ${ }^{2+}$ nanoparticles in addition to purification and thereby increasing its stability. The excellent reusability of immobilized enzymes is of great importance as it decreases the cost of industrial applications. 
Taking into account their substrate specificity, Bgluc has been classified into three groups: cellobiases (high specificity for cellobiose), aryl- $\beta$-glucosidases (high specificity for substrates such as $p$-NPG), or wide range Bgluc, which exhibit broad activities on various types of substrates [67]. Bgluc from C. formosanus shows higher affinity and activity toward cellobiose and cellotriose than other substrates [20]. The G1mgNtBG1 has broad substrate specificity and hydrolyzes both natural and synthetic substrates [29]. The Bgluc form G. sulphureus was active on the $p$-NPG and cellobiose, but inactive on avicel [44]. Bgluc from $R$. flavipes was most active against $p$-NPG, cellobiose, salicin, and laminaribose [25]. Our previous study revealed that BglucH showed high activity toward $p$-NPG, cellobiose, cellotriose and lactosum [5]. Here, the Bgluc activity was measured using $p$-NPG, because its hydrolysis can be directly quantified in colorimetric assays. It should be noted that there are several limitations because the activity of Bgluc was only examined on $p$-NPG, and it would be interesting to have an activity with cellobiose or cellotriose that are the natural substrate of Bgluc. To improve the large-scale application of the biocatalyst in biomass conversion, lignocellulose saccharification experiments is necessitated in further research.

\section{Conclusions}

Bgluc, an important member of the cellulose system, plays a critical role in the enzymatic hydrolysis of biomass for the production of biofuels. In this study, a novel binary ELP\&His tag was fused with Bgluc from C. formosanus to construct a Bgluc-linker-ELP-His recombinant fusion protein (BglucLEH). The recovery rate and purification fold of the fusion enzyme BglucLEH reached $77.78 \%$ and 12.60 , respectively, through ITC with $0.5 \mathrm{M}$ $\left(\mathrm{NH}_{4}\right)_{2} \mathrm{SO}_{4}$ based on the ELP tag. The purification by ITC was superior to the traditional Ni-NTA resin. Moreover, the ELP did not affect the enzyme activity, kinetic parameters and secondary structure of Bgluc. More importantly, ELP improved the Bgluc stability in harsh conditions such as heating and exposure to denaturant.

\section{Materials and methods Materials}

The expression vector $\mathrm{pET} 28 \mathrm{a}(+)$ and $E$. coli strains BL21 (DE3), were stored at $-80{ }^{\circ} \mathrm{C}$ in our lab. Kanamycin, protease inhibitors phenylmethanesulfonyl fluoride (PMSF) and IPTG were purchased from Sangon Biotech (Shanghai, China). $p$-NPG was purchased from Bio Teke Corporation (Beijing, China). Glycine, Tris, SDS, Bromophenol blue, coomassie brilliant blue $\mathrm{R} 250$ and $p$-nitrophenol ( $p$-NP) were purchased from San gon Biotech (Shanghai, China). Acrylamide and TEMED were bought from Sigma (USA). Glycerinum, isopropanol, methyl alcohol, $\beta$-mercaptoethanol, ammonium persulfate and glacial acetic acid were obtained from Sinopharm Chemical Reagent (Shanghai, China). Thermo Scientific Pierce BCA Protein Assay Kit was purchased from Thermo Fisher Scientific (MA, USA). High Affinity Ni-NTA Resin was bought from Genscript (Nanjing, China). All other reagents were of analytical grade and used without any further treatment.

\section{Construction of recombinant expression plasmids (BglucLEH and BglucH)}

The amino acid coding sequences for Bgluc of C. formosanus was derived from gene (GQ911585) at GenBank NCBI. The 50 repeating pentapeptide sequence, ValPro-Gly-Val-Gly (VPGVG) ${ }_{50}$, was designed (denoted as ELP). The Bgluc and ELP genes were fused together with a flexible linker (GGGGS) ${ }_{3}$ and adding a $6 x$ His-tag to the $3^{\prime}$ of the fusion gene. The schematic diagram, nucleotide sequence and restriction enzyme sites are shown in Fig. 1. The nucleotide sequence of the designed fusion protein was synthesized by Synbio Tech (Jiangsu, China), and subcloned into pET28a(+) resulting in the recombinant expression of the plasmid pET28a(+)-BglucLEH (Bgluc-Linker-ELP-His) (Fig. 1). The recombinant plasmid pET28a(+)-Bgluc (BglucH) expressing a His-tagged Bgluc was previously constructed in our lab [5].

\section{Production of recombinant proteins (BglucLEH and BglucH)}

The constructed recombinant expressional plasmids pET28a(+)-BglucLEH, pET28a(+)-BglucH and empty vector $\mathrm{pET} 28 \mathrm{a}(+)$ were transformed into the $E$. coli strain BL21 (DE3) for protein production. A freshly transformed single colony was inoculated in LB media with $50 \mu \mathrm{g} / \mathrm{mL}$ kanamycin and cultured overnight in an orbital shaker at $37^{\circ} \mathrm{C}$ with shaking (200 rpm). Two milliliters of this culture was inoculated into $200 \mathrm{~mL}$ of fresh medium supplemented with $50 \mu \mathrm{g} / \mathrm{mL}$ kanamycin. When $\mathrm{OD}_{600}$ of culture reached 0.4, IPTG was then added to a final concentration of $1 \mathrm{mM}$, and the cells were grown at $25^{\circ} \mathrm{C}$ or $37^{\circ} \mathrm{C}$ for $16-20 \mathrm{~h}$. Cells were harvested by centrifuging at $4500 \times g$ at $4{ }^{\circ} \mathrm{C}$ for $20 \mathrm{~min}$, and cell pellets were stored at $-80{ }^{\circ} \mathrm{C}$. The cell pellets were thawed and resuspended in $10 \mathrm{~mL}$ Tris $-\mathrm{HCl}(50 \mathrm{mM}, \mathrm{pH} 8.0)$ and the cells were washed twice with Tris- $\mathrm{HCl}$. Finally, the cells were resuspended in $5 \mathrm{~mL}$ Tris- $\mathrm{HCl}$ buffer with $1 \mathrm{mM}$ PMSF. The cells were broken by sonication for $30 \mathrm{~min}$ using ultrasonic cell disruptor, with alternately sonication at $10 \mathrm{~s}$ and intermittent periods of cooling $10 \mathrm{~s}$. The supernatant and precipitate were separated by centrifugation twice at $12,000 \times g$ for $20 \mathrm{~min}$ at $4{ }^{\circ} \mathrm{C}$. 


\section{Purification of fusion proteins}

\section{(1) Purification by Ni-charged resin (BglucLEH and BglucH)}

The recombinant proteins (BglucLEH and BglucH) were purified with Ni-NTA resin because both the BglucLEH and BglucH contain His tag. Purification conditions followed the manufacturer's instructions. Briefly, the crude cell lysates were mixed with the Ni-NTA resin and incubated at $4{ }^{\circ} \mathrm{C}$ for $2 \mathrm{~h}$. Subsequently, the surplus cell lysates flowed through the column while target protein was retained. $\mathrm{Ni}$ NTA resin was washed with $3-\mathrm{mL}$ solution I $(50 \mathrm{mM}$ Tris, $\mathrm{pH}$ 8.0, $300 \mathrm{mM} \mathrm{NaCl}, 50 \mathrm{mM}$ imidazole), then 3-mL solution II (50 mM Tris, pH8.0, $300 \mathrm{mM} \mathrm{NaCl}, 100 \mathrm{mM}$ imidazole). Finally, His-tagged protein (BglucLEH or BglucH) was eluted from $\mathrm{Ni}$-charged resin with 2-mL solution III (50 mM Tris, pH 8.0, $300 \mathrm{mM} \mathrm{NaCl}, 400 \mathrm{mM}$ imidazole). The eluted protein was dialyzed against dialysis buffer (50 mM Tris- $\mathrm{HCl}, \mathrm{pH} 8.0$ ) at $4{ }^{\circ} \mathrm{C}$ to remove imidazole. The concentration of purified proteins (BglucLEH and BglucH) was determined by the Pierce ${ }^{\circledR}$ BCA Protein Assay Kit.

\section{(2) Purification by ITC (BglucLEH)}

BglucLEH also was purified with different salt (the salt being investigated at its specified concentration, dissolved in water) including $1 \mathrm{M} \mathrm{NaH} \mathrm{PO}_{4}, 1 \mathrm{M}\left(\mathrm{NH}_{4}\right)_{2} \mathrm{SO}_{4}, 1 \mathrm{M}$ $\mathrm{Na}_{2} \mathrm{SO}_{4}, 2.5 \mathrm{M} \mathrm{NaCl}$ because BglucLEH contains ELP tag. After SDS-PAGE analysis, $\left(\mathrm{NH}_{4}\right)_{2} \mathrm{SO}_{4}$ was selected as the purification salt.

To determine the concentration of $\left(\mathrm{NH}_{4}\right)_{2} \mathrm{SO}_{4}$, BglucLEH was purified with various concentrations of $\left(\mathrm{NH}_{4}\right)_{2} \mathrm{SO}_{4}(0.3$, 0.5, 0.7 and $1.0 \mathrm{M})$. First, a certain amount of $\left(\mathrm{NH}_{4}\right)_{2} \mathrm{SO}_{4}$ was added into $500-\mu \mathrm{L}$ crude extract, and the mixed solution was incubated for $20 \mathrm{~min}$ and then centrifuged at $12,000 \times g$ for $10 \mathrm{~min}$ at room temperature $\left(25^{\circ} \mathrm{C}\right)$ (termed "hot spin"). The supernatant was withdrawn and discarded, and the pellet containing BglucLEH was redissolved in cold Tris- $\mathrm{HCl}$ buffer at $4{ }^{\circ} \mathrm{C}$ for $30-60 \mathrm{~min}$. Then, a centrifugation step at $4{ }^{\circ} \mathrm{C}$ for $10 \mathrm{~min}$ (termed "cold spin") is carried out to remove contaminants that may have been physically trapped in BglucLEH. The supernatant containing BglucLEH supernatant from the cold spin is retained, and the pellet is discarded. This process constitutes one round of ITC. The concentration of protein (BglucLEH) was determined by the Pierce ${ }^{\circledR}$ BCA Protein Assay Kit. The recovery rate and purification refold of fusion proteins were determined by enzyme activity measurement.

$$
\begin{aligned}
& \text { Recovery rate (\%) } \\
& \qquad=\frac{\text { Purified enzyme activity }}{\text { Total enzyme activity in crude extract }} \times 100 \\
& \text { Purification fold } \\
& \quad=\frac{\text { Specific activity of purified enzyme }}{\text { Specific activity of crude enzyme }}
\end{aligned}
$$

\section{Enzyme activity assay}

The activity of Bgluc was measured as described in our previous study [65]. Briefly, a certain amount of BglucLEH or BglucH was incubated with $5 \mathrm{mM} p$-NPG, $50 \mathrm{mM} \mathrm{NaAc}-$ HAc $(\mathrm{pH} 5.5)$ buffer at $40{ }^{\circ} \mathrm{C}$. Assays were terminated $10 \mathrm{~min}$ later by the addition of $1 \mathrm{M} \mathrm{Na}_{2} \mathrm{CO}_{3}$. The amount of $p$-NP released was determined at $410 \mathrm{~nm}$ with spectrophotometer. The specific activity (U) was defined as the amount of enzyme that releases $1 \mu \mathrm{mol}$ of catalytic product $p$-NP per min.

\section{Kinetic parameter activity assay}

The kinetic parameters such as the Michaelis constant $\left(K_{\mathrm{m}}\right)$, maximum velocity $\left(V_{\max }\right)$ and turnover number $\left(k_{\mathrm{cat}}\right)$ for BglucH and BglucLEH enzymes were measured using $p$-NPG at 1-14 mM. Reactions were carried out in $50 \mathrm{mM}$ sodium acetate buffer ( $\mathrm{pH}$ 5.5) with purified BglucH and BglucLEH at $40{ }^{\circ} \mathrm{C}$ and were stopped by adding $1 \mathrm{M}$ $\mathrm{Na}_{2} \mathrm{CO}_{3}$. The $K_{\mathrm{m}}$ and $V_{\max }$ were calculated according to the Lineweaver-Burk method.

\section{Secondary structure of BglucH and BglucLEH}

The CD spectra of BglucLEH enzyme and BglucH were recorded at a wavelength of 190-250 $\mathrm{nm}$ with a JASCO810 spectropolarimeter (Jasco, Tokyo, Japan) and a quartz cell with $0.1 \mathrm{~mm}$ optical path length. All spectra were corrected by subtracting a blank spectrum (buffer without enzyme). The purified enzyme BglucH and BglucLEH solutions were prepared by dissolving the enzymes in PBS buffer to a final concentration of $0.1 \mathrm{mg} / \mathrm{mL}$. The measurements were performed at $25^{\circ} \mathrm{C}$.

\section{Effect of $\mathrm{pH}$ and temperature on BglucH and BglucLEH Activity}

$p$-NPG was used as the substrate for activity assays to investigate optimum temperature and $\mathrm{pH}$. The purified BglucH and BglucLEH were incubated with substrate ( $p$ NPG) at various temperatures that ranged from 20 to $80{ }^{\circ} \mathrm{C}$ $(\mathrm{pH} 5.5)$ or in buffers over a $\mathrm{pH}$ range of $3.0-8.0\left(40{ }^{\circ} \mathrm{C}\right)$ for $10 \mathrm{~min}$. Then, the catalytic activity was then measured as described above.

\section{Enzyme stability}

The stability of BglucH and BglucLEH was investigated, which included storage, thermal stability and resistance to chemical denaturant. For storage stability, purified BglucH and BglucLEH were stored in $4{ }^{\circ} \mathrm{C}$ and $25^{\circ} \mathrm{C}$, and the specific enzyme activity was measured at $4{ }^{\circ} \mathrm{C}$ and $25{ }^{\circ} \mathrm{C}$ every 4 days for 28 days. The residual specific enzyme activity of BglucH and BglucLEH reduced over time in comparison to enzyme activity measured initially. The results presented are the average of three independent experiments. 
The thermal and $\mathrm{pH}$ stability of BglucH and BglucLEH were measured according to the method described in our previous studies $[65,66]$. Briefly, the purified BglucH and BglucLEH were pre-incubated without substrate $(p$-NPG) at various temperatures $(20,30,40,50,60,70$, $80{ }^{\circ} \mathrm{C}$ ) and $\mathrm{pH} 5.5$ for $30 \mathrm{~min}$. Then, the residual enzyme activities of BglucH and BglucLEH were evaluated using $p$-NPG at under standard conditions $\left(\mathrm{pH} 5.5,40{ }^{\circ} \mathrm{C}\right.$ and $10 \mathrm{~min}$ ). To estimate $\mathrm{pH}$ stability, the enzyme was preincubated in buffers over a $\mathrm{pH}$ range of 3.0-8.0 without substrate at $40{ }^{\circ} \mathrm{C}$ for $30 \mathrm{~min}$, and the residual activities were measured using $p$-NPG under the standard conditions ( $\mathrm{pH} 5.5,40^{\circ} \mathrm{C}$ and $10 \mathrm{~min}$ ). The maximum activity value was set as value obtained by enzymes exposed to optimum temperature.

To assess the BglucH and BglucLEH resistance to chemical denaturant, the purified BglucH and BglucLEH were incubated with various concentrations of chaotropic reagent guanidine hydrochloride $(0,0.5,1,1.5,2,2.5,3,4$, $5,6 \mathrm{M}$ ) at room temperature for $30 \mathrm{~min}$, respectively. The $\mathrm{CD}$ analysis was then measured as described above.

\section{Additional file}

Additional file 1: Figure S1. SDS-PAGE analysis of BglucH and BglucLEH enzyme. (a): SDS-PAGE analysis of BglucH enzyme and BglucLEH enzyme induce at $37^{\circ} \mathrm{C}$. Lane $\mathrm{M}$, Protein molecular weight marker (Broad); Lane 1, cell lysates of BglucH induced 0 h; Lane 2, cell lysates of BglucH induced 8 h; Lane 3, precipitation lysates containing BglucH; Lane 4, crude cell lysate of BglucH; Lane 5, crude cell lysate of empty pET-28a(+) vector; Lane 6 , cell lysates of BglucLEH induced 0 h; Lane 7, cell lysates of BglucLEH induced 8 h; Lane 8: precipitation lysates containing BglucLEH; Lane 9, crude cell lysate of $\mathrm{BglucH}$; The arrows in the figure are the insoluble fractions of the BglucH enzyme and the BglucLEH enzyme. (b): SDS-PAGE analysis of BglucH enzyme and BglucLEH enzyme induced at $25^{\circ} \mathrm{C}$. Lane M, Protein molecular weight marker (Broad); Lane 1, cell lysates of BglucH induced 0 h; Lane 2, cell lysates of BglucH induced 8 h; Lane 3, precipitation lysates containing BglucH; Lane 4, crude cell lysate of BglucH; Lane 5 , crude cell lysate of empty pET-28a(+) vector; Lane 6, cell lysates of BglucLEH induced $0 \mathrm{~h}$; Lane 7, cell lysates of BglucLEH induced $8 \mathrm{~h}$; Lane 8: precipitation lysates containing BglucLEH; Lane 9, crude cell lysate of BglucH; The red wireframe in the figure indicates the whole bacteria, sediment and supernatant solution containing BglucH enzyme and BglucLEH enzyme, respectively. Figure S2. SDS-PAGE analysis of BglucH induced at $25^{\circ} \mathrm{C}$ and purification by Ni-NTA resin. Lane M, Protein molecular weight marker (Broad); Lane 1, crude cell lysate of cell with empty pET-28a(+) vector; Lane 2, crude cell lysate containing BglucH; Lanes 3-4, purified BglucH by Ni-NTA resin. Figure S3. SDS-PAGE analysis of twice ITC and $400 \mathrm{mM}$ imidazole purified BglucLEH. Lane M, Protein molecular weight marker (Broad); Lane 1, crude cell lysate of cell with empty pET28a(+) vector; Lane 2, crude cell lysate containing BglucLEH; Lanes 3-4, BglucLEH purified after one and two rounds of ITC operation using 0.5 $\mathrm{M}$ of $\left(\mathrm{NH}_{4}\right)_{2} \mathrm{SO}_{4}$. Figure S4. Lineweaver-Burk plots for (a) BglucLEH, (b) BglucLEH.

\section{Abbreviations}

Bgluc: $\beta$-glucosidase; BglucH: Bgluc-His; ELP: elastin-like polypeptide; BglucLEH: Glu-linker-ELP-His; ITC: inverse transition cycling; $\mathrm{T}_{t}$ : phase transition temperature; $\mathrm{CD}$ : circular dichroism; $p$-NPG: p-nitrophenyl- $\beta$-D-glucopyranoside; CLP: collagen-like polypeptide; PMSF: phenylmethanesulfonyl fluoride; IPTG: isopropyl-beta-D-thiogalactopyranoside; $p$-NP: $p$-nitrophenol.

\section{Acknowledgements}

Not applicable.

\section{Authors' contributions}

$Y Z, X L, D Y, X J$ and $Y W W$ contributed to design the research and performed experiments and wrote the article. YZ designed the recombinant gene. FEE and FAP edited the article. YYW and JG analyzed and interpreted data. FL and HS designed experiments, and reviewed all data and article. All authors read and approved the final manuscript.

\section{Funding}

This work was supported by the National Natural Science Foundation of China (31301919, 31271272), Natural Science Foundation of Jiangsu Province (BK20130506), the major project of Science and Technology of Zhejiang Province (2018C02019) and Natural Science Foundation of the Higher Education Institutions of Jiangsu Province (13KJB18005).

\section{Availability of data and materials}

$\beta$-Glucosidase sequence is deposited in GenBank under the Accession Number GQ911585.

\section{Ethics approval and consent to participate}

Not applicable.

\section{Consent for publication}

The authors have consented for publication.

\section{Competing interests}

The authors declare that they have no competing interests. All authors agree to authorship and approved the final manuscript.

Received: 2 February 2019 Accepted: 11 June 2019

Published online: 24 June 2019

\section{References}

1. Ni JF, Tokuda G. Lignocellulose-degrading enzymes from termites and their symbiotic microbiota. Biotechnol Adv. 2013;31:838-50.

2. Ferreira RDG, Azzoni AR, Freitas S. Techno-economic analysis of the industrial production of a low-cost enzyme using E. coli: the case of recombinant beta-glucosidase. Biotechnol Biofuels. 2018;11:81.

3. Kuusk S, Valjamae P. When substrate inhibits and inhibitor activates: implications of beta-glucosidases. Biotechnol Biofuels. 2017;10:7.

4. Tokuda G, Watanabe H, Hojo M, Fujita A, Makiya H, Miyagi M, et al. Cellulolytic environment in the midgut of the wood-feeding higher termite Nasutitermes takasagoensis. J Insect Physiol. 2012;58:147-54.

5. Feng $T$, Liu H, Xu Q, Sun J, Shi H. Identification and characterization of two endogenous beta-glucosidases from the termite coptotermes formosanus. Appl Biochem Biotechnol. 2015;176:2039-52.

6. Liew KJ, Lim L, Woo HY, Chan KG, Shamsir MS, Goh KM. Purification and characterization of a novel $\mathrm{GH} 1$ beta-glucosidase from Jeotgalibacillus malaysiensis. Int J Biol Macromol. 2018;115:1094-102.

7. Mendez-Liter JA, de Eugenio LI, Prieto A, Martinez MJ. The beta-glucosidase secreted by Talaromyces amestolkiae under carbon starvation: a versatile catalyst for biofuel production from plant and algal biomass. Biotechnol Biofuels. 2018;11:123.

8. Gao J, Qian Y, Wang Y, Qu Y, Zhong Y. Production of the versatile cellulase for cellulose bioconversion and cellulase inducer synthesis by genetic improvement of Trichoderma reesei. Biotechnol Biofuels. 2017;10:272.

9. Tiwari R, Singh PK, Singh S, Nain PKS, Nain L, Shukla P. Bioprospecting of novel thermostable beta-glucosidase from Bacillus subtilis RA10 and its application in biomass hydrolysis. Biotechnol Biofuels. 2017;10:246.

10. Yeboah A, Cohen RI, Rabolli C, Yarmush ML, Berthiaume F. Elastin-like polypeptides: a strategic fusion partner for biologics. Biotechnol Bioeng. 2016;113:1617-27.

11. Dan EM, Chilkoti A. Purification of recombinant proteins by fusion with thermally-responsive polypeptides. Nat Biotechnol. 1999;17:1112. 
12. Christensen T, Trabbic-Carlson K, Liu W, Chilkoti A. Purification of recombinant proteins from Escherichia coli at low expression levels by inverse transition cycling. Anal Biochem. 2007;360:166-8.

13. Araújo A, Olsen BD, Machado AV. Engineering elastin-like polypeptidepoly(ethylene glycol) multiblock physical networks. Biomacromol. 2018;19:329-39.

14. Christensen T, Hassouneh W, Trabbic-Carlson K, Chilkoti A. Predicting transition temperatures of elastin-like polypeptide fusion proteins. Biomacromol. 2013;14:1514-9.

15. Gutiérrez SP, Saberianfar R, Kohalmi SE, Menassa R. Protein body formation in stable transgenic tobacco expressing elastin-like polypeptide and hydrophobin fusion proteins. BMC Biotechnol. 2013;13:1-11.

16. Shi C, Meng Q, Wood DW. A dual ELP-tagged split intein system for non-chromatographic recombinant protein purification. Appl Microbiol Biotechnol. 2013;97:829.

17. Lin F, Yan D, Chen Y, E FE, Shi H, Han B, et al. Cloning, purification and enzymatic characterization of recombinant human superoxide dismutase 1 (hSOD1) expressed in Escherichia coli. Acta Biochim Pol. 2018;65:235-40.

18. Huo J, Shi H, Yao Q, Chen H, Wang L, Chen K. Cloning and purification of recombinant silkworm dihydrolipoamide dehydrogenase expressed in Escherichia coli. Protein Expr Purif. 2010;72:95-100.

19. Shimada K, Maekawa K. Gene expression and molecular phylogenetic analyses of beta-glucosidase in the termite Reticulitermes speratus (Isoptera: Rhinotermitidae). J Insect Physiol. 2014;65:63-9.

20. Zhang D, Allen AB, Lax AR. Functional analyses of the digestive betaglucosidase of Formosan subterranean termites (Coptotermes formosanus) J Insect Physiol. 2012;58:205-10.

21. Zhang DH, Lax AR, Bland JM, Yu JJ, Fedorova N, Nierman WC. Hydrolysis of filter-paper cellulose to glucose by two recombinant endogenous glycosyl hydrolases of Coptotermes formosanus. Insect Sci. 2010;17:245-52.

22. Cairo JP, Oliveira LC, Uchima CA, Alvarez TM, Citadini AP, Cota J, et al. Deciphering the synergism of endogenous glycoside hydrolase families 1 and 9 from Coptotermes gestroi. Insect Biochem Mol Biol. 2013;43:970-81.

23. Franco Cairo JP, Leonardo FC, Alvarez TM, Ribeiro DA, Buchli F, CostaLeonardo AM, et al. Functional characterization and target discovery of glycoside hydrolases from the digestome of the lower termite Coptotermes gestroi. Biotechnol Biofuels. 2011;4:50.

24. Matsuura K, Yashiro T, Shimizu K, Tatsumi S, Tamura T. Cuckoo fungus mimics termite eggs by producing the cellulose-digesting enzyme betaglucosidase. Curr Biol. 2009;19:30-6.

25. Scharf ME, Kovaleva ES, Jadhao S, Campbell JH, Buchman GW, Boucias DG. Functional and translational analyses of a beta-glucosidase gene (glycosyl hydrolase family 1 ) isolated from the gut of the lower termite Reticulitermes flavipes. Insect Biochem Mol Biol. 2010;40:611-20.

26. Wu Y, Chi S, Yun C, Shen Y, Tokuda G, Ni J. Molecular cloning and characterization of an endogenous digestive beta-glucosidase from the midgut of the fungus-growing termite Macrotermes barneyi. Insect Mol Biol. 2012;21:604-14.

27. Uchima CA, Tokuda G, Watanabe H, Kitamoto K, Arioka M. Heterologous expression and characterization of a glucose-stimulated beta-glucosidase from the termite Neotermes koshunensis in Aspergillus oryzae. Appl Microbiol Biotechnol. 2011;89:1761-71.

28. Tokuda G, Miyagi M, Makiya H, Watanabe H, Arakawa G. Digestive betaglucosidases from the wood-feeding higher termite, Nasutitermes takasagoensis: intestinal distribution, molecular characterization, and alteration in sites of expression. Insect Biochem Mol Biol. 2009;39:931-7.

29. Uchima CA, Tokuda G, Watanabe H, Kitamoto K, Arioka M. Heterologous expression in Pichia pastoris and characterization of an endogenous thermostable and high-glucose-tolerant beta-glucosidase from the termite Nasutitermes takasagoensis. Appl Environ Microbiol. 2012;78:4288-93.

30. Arthornthurasuk S, Jenkhetkan W, Suwan E, Chokchaichamnankit D, Srisomsap C, Wattana-Amorn P, et al. Molecular characterization and potential synthetic applications of $\mathrm{GH} 1$ beta-glucosidase from higher termite Microcerotermes annandalei. Appl Biochem Biotechnol. 2018;186:877-94.

31. Zouhar J, Nanak E, Brzobohaty B. Expression, single-step purification, and matrix-assisted refolding of a maize cytokinin glucoside-specific betaglucosidase. Protein Expr Purif. 1999;17:153-62.

32. Mendez-Liter JA, Gil-Munoz J, Nieto-Dominguez M, Barriuso J, de Eugenio LI, Martinez MJ. A novel, highly efficient beta-glucosidase with a cellulose-binding domain: characterization and properties of native and recombinant proteins. Biotechnol Biofuels. 2017;10:256.
33. Bonfá EC, Maria DSMM, Gomes E, Bonilla-Rodriguez GO. Biochemical characterization of an isolated $50 \mathrm{kDa}$ beta-glucosidase from the thermophilic fungus Myceliophthora thermophila M.7.7. Biocatal Agric Biotechnol. 2018;13:311-8.

34. Gao L, Gao F, Zhang D, Zhang C, Wu G, Chen S. Purification and characterization of a new beta-glucosidase from Penicillium piceum and its application in enzymatic degradation of delignified corn stover. Bioresour Technol. 2013;147:658-61.

35. McCarthy B, Yuan Y, Koria P. Elastin-like-polypeptide based fusion proteins for osteogenic factor delivery in bone healing. Biotechnol Progr. 2016;32:1029-37.

36. Chen M, Zhao J, Xia LM. Enzymatic hydrolysis of maize straw polysaccharides for the production of reducing sugars. Carbohydr Polym. 2008;71:411-5.

37. Xia W, Xu X, Qian L, Shi P, Bai Y, Luo H, et al. Engineering a highly active thermophilic beta-glucosidase to enhance its $\mathrm{pH}$ stability and saccharification performance. Biotechnol Biofuels. 2016;9:147.

38. Korotkova OG, Semenova MV, Morozova VV, Zorov IN, Sokolova LM, Bubnova TM, et al. Isolation and properties of fungal beta-glucosidases. Biochemistry (Mosc). 2009;74:569-77.

39. Yan TR, Lin YH, Lin CL. Purification and characterization of an extracellular beta-glucosidase II with high hydrolysis and transglucosylation activities from Aspergillus niger. J Agric Food Chem. 1998;46:431-7.

40. Karnaouri A, Topakas E, Paschos T, Taouki I, Christakopoulos P. Cloning, expression and characterization of an ethanol tolerant GH3 beta-glucosidase from Myceliophthora thermophila. PeerJ. 2013;1:e46.

41. Parry NJ, Beever DE, Owen E, Vandenberghe I, Van Beeumen J, Bhat MK. Biochemical characterization and mechanism of action of a thermostable beta-glucosidase purified from Thermoascus aurantiacus. Biochem J. 2001;353:117-27

42. Krogh KB, Harris PV, Olsen CL, Johansen KS, Hojer-Pedersen J, Borjesson J, et al. Characterization and kinetic analysis of a thermostable $\mathrm{GH} 3$ beta-glucosidase from Penicillium brasilianum. Appl Microbiol Biotechnol. 2010;86:143-54.

43. Yoon JJ, Kim KY, Cha CJ. Purification and characterization of thermostable beta-glucosidase from the brown-rot basidiomycete Fomitopsis palustris grown on microcrystalline cellulose. J Microbiol. 2008;46:51-5.

44. Wang Q, Qian C, Zhang XZ, Liu N, Yan X, Zhou Z. Characterization of a novel thermostable beta-glucosidase from a metagenomic library of termite gut. Enzyme Microb Technol. 2012;51:319-24.

45. Floss DM, Sack M, Arcalis E, Stadlmann J, Quendler H, Rademacher T, et al. Influence of elastin-like peptide fusions on the quantity and quality of a tobacco-derived human immunodeficiency virus-neutralizing antibody. Plant Biotechnol J. 2009;7:899-913.

46. Meyer DE, Trabbic-Carlson K, Chilkoti A. Protein purification by fusion with an environmentally responsive elastin-like polypeptide: effect of polypeptide length on the purification of thioredoxin. Biotechnol Progr. 2001;17:720-8.

47. Kang HJ, Kim JH, Chang WJ, Kim ES, Koo YM. Heterologous expression and optimized one-step separation of levansucrase via elastin-like polypeptides tagging system. J Microbiol Biotechnol. 2007;17:1751-7.

48. Chow DC, Dreher MR, Trabbic-Carlson K, Chilkoti A. Ultra-high expression of a thermally responsive recombinant fusion protein in E. coli. Biotechnol Prog. 2006;22:638-46.

49. Floss DM, Sack M, Stadlmann J, Rademacher T, Scheller J, Stoger E, et al. Biochemical and functional characterization of anti-HIV antibody-ELP fusion proteins from transgenic plants. Plant Biotechnol J. 2008;6:379-91.

50. Koria P, Yagi H, Kitagawa Y, Megeed Z, Nahmias Y, Sheridan R, et al. Self-assembling elastin-like peptides growth factor chimeric nanoparticles for the treatment of chronic wounds. Proc Natl Acad Sci USA. 2011;108:1034-9.

51. Christensen T, Amiram M, Dagher S, Trabbic-Carlson K, Shamji MF, Setton LA, et al. Fusion order controls expression level and activity of elastin-like polypeptide fusion proteins. Protein Sci. 2009;18:1377-87.

52. Fletcher EE, Yan D, Kosiba AA, Zhou Y, Shi H. Biotechnological applications of elastin-like polypeptides and the inverse transition cycle in the pharmaceutical industry. Protein Expr Purif. 2019;153:114-20.

53. Liu W, Hong J, Bevan DR, Zhang YH. Fast identification of thermostable beta-glucosidase mutants on cellobiose by a novel combinatorial selection/screening approach. Biotechnol Bioeng. 2009;103:1087-94. 
54. Lee $\mathrm{HL}$, Chang $\mathrm{CK}$, Jeng WY, Wang AH, Liang PH. Mutations in the substrate entrance region of beta-glucosidase from Trichoderma reesei improve enzyme activity and thermostability. Protein Eng Des Sel. 2012;25:733-40.

55. Pei XQ, Yi ZL, Tang CG, Wu ZL. Three amino acid changes contribute markedly to the thermostability of beta-glucosidase BglC from Thermobifida fusca. Bioresour Technol. 2011;102:3337-42.

56. StrohI WR. Fusion proteins for half-life extension of biologics as a strategy to make biobetters. BioDrugs. 2015;29:215-39.

57. Liu D, Du K, Feng W. Immobilization of enzymes using a multifunctional fusion polypeptide. Biotechnol Lett. 2018;40:181-7.

58. Conrad U, Plagmann I, Malchow S, Sack M, Floss DM, Kruglov AA, Nedospasov SA, Rose-John S, Scheller J. ELPylated anti-human TNF therapeutic single-domain antibodies for prevention of lethal septic shock. Plant Biotechnol J. 2011;9:22-31.

59. Cho Y, Sagle LB, limura S, Zhang Y, Kherb J, Chilkoti A, Cremer PS, et al. Hydrogen bonding of beta-turn structure is stabilized in D(2)O. J Am Chem Soc. 2009;131:15188-93.

60. Vogt G, Woell S, Argos P. Protein thermal stability, hydrogen bonds, and ion pairs. J Mol Biol. 1997:269:631-43.

61. Ge X, Yang DSC, Trabbic-Carlson K, Kim B, Chilkoti A, Filipe CDM. Selfcleavable stimulus responsive tags for protein purification without chromatography. J Am Chem Soc. 2005;127:11228-9.
62. Banki MR, Feng L, Wood DW. Simple bioseparations using self-cleaving elastin-like polypeptide tags. Nat Methods. 2005;2:659-61.

63. Fong BA, Wood DW. Expression and purification of ELP-intein-tagged target proteins in high cell density E. coli fermentation. Microb Cell Fact. 2010;9:77.

64. Liu F, Tsai SL, Madan B, Chen W. Engineering a high-affinity scaffold for non-chromatographic protein purification via intein-mediated cleavage. Biotechnol Bioeng. 2012;109:2829-35.

65. Zhou Y, Yuan S, Liu Q, Yan D, Wang Y, Gao L, et al. Synchronized purification and immobilization of his-tagged beta-glucosidase via Fe3O4/PMG core/shell magnetic nanoparticles. Sci Rep. 2017;7:41741.

66. Zhou Y, Yan D, Yuan S, Chen Y, Fletcher EE, Shi H, et al. Selective binding, magnetic separation and purification of histidine-tagged protein using biopolymer magnetic core-shell nanoparticles. Protein Expr Purif. 2018;144:5-11.

67. Sorensen A, Lubeck M, Lubeck PS, Ahring BK. Fungal Beta-glucosidases: a bottleneck in industrial use of lignocellulosic materials. Biomolecules. 2013;3:612-31.

\section{Publisher's Note}

Springer Nature remains neutral with regard to jurisdictional claims in published maps and institutional affiliations.
Ready to submit your research? Choose BMC and benefit from:

- fast, convenient online submission

- thorough peer review by experienced researchers in your field

- rapid publication on acceptance

- support for research data, including large and complex data types

- gold Open Access which fosters wider collaboration and increased citations

- maximum visibility for your research: over $100 \mathrm{M}$ website views per year

At BMC, research is always in progress.

Learn more biomedcentral.com/submissions 